\title{
独立学院档案学专业教学改革探讨一以苏州大学文正学院 为例
}

张明吴琳月

苏州大学文正学院

DOI:10.32629/er.v2i8.1955

[摘 要] 独立学院是以培养适应经济社会发展的高素质应用型人才为目标, 其教学模式与普通高校有一定的差异性, 在提升 学生理论水平的同时, 更需加强学生实践能力的培养。档案学专业是一门实践性很强的学科, 需要不断创新教学模式, 培养具有 高素质的专门人才。本文以苏州大学文正学院档案学专业为例, 通过课程设置、教学方式、实践教学、师资队伍等四个方面 的现状分析, 为独立学院档案学专业教学改革提出相关建议。

[关键词] 独立学院; 档案学专业; 教学改革; 课程设置

为了适应经济社会发展的需要, 独立学院的办学目标朝 着应用型本科教育方向转型已成必然趋势。独立学院设置的 档案学专业重在通过教学改革, 完善课程体系, 更新教学内 容、优化教学环节、创新教学方法, 全面提高教学水平, 培养 具有较强社会适应能力和竞争能力的高素质应用型人才。

\section{1 档案学专业发展现状及其特点}

档案学专业主要培养能适应现代信息社会和市场经济 需要, 能在国家机关、企事业单位的档案机构、信息部门从 事档案信息服务、档案信息管理等工作的高素质应用型人 才。目前我国已有 30 多所高等院校开设档案学专业, 经济社 会的快速发展对于档案人才要求不断提高, 推动着档案学专 业高等教育的发展。

苏州大学文正学院是在我国高等教育大变革、大发展背 景下应运而生的第一所独立学院。办学近二十年来, 学院积 极将改革创新作为事业前进的指导思想, 充分发挥母体资源 优势, 专业设置和师资选聘均与苏州大学相关学院共建和考 评。文正学院成立初期就设立了档案学本科专业, 学制 4 年。 该专业依托来自母体苏州大学自1983年起设立的国家级特 色档案学专业。文正学院在依托母体的同时, 积极探索教学 改革路径, 充分体现独立学院档案学专业的时代性、实践性、 应用型特色。

\section{2 档案学专业教学状况调查与分析}

本研究以文正学院档案学专业2013届至2017届的学生 为调查对象, 运用问卷和访谈相结合的方法, 对档案学专业 教学状况进行分析。调查问卷发放200份, 回收144份全部有 效, 有效回收率 $72 \%$ 。

\section{1课程设置与专业特色}

档案学专业课程主要包括三大模块: 通识课程、专业必 修课程、特色课程。调查显示, 在前十多年的教学课程设置 中, 主要是对选修课程的变动较多, 专业课程设置变化较小。 必修课程是档案学专业的核心课程, 是学生对于档案认识和 学习的关键, 必修课程涉及多个专业领域, 课程安排长期是
以讲授为主, 一般为 17 周课程, 总学时有 $54 、 51 、 34$ 不等, 每 门课程设计为 $2-3$ 学分。在课程设置调查中, 有 $55.56 \%$ 的同学 表示课程设置具有专业特色、但还不够凸显。由于大部分课 程学时只为讲授学时, 实践课程太少, 学时设置单一。课程学 分设置较为笼统, 不够具体细化。

\section{2 教学方式现状及其影响}

调查表明, 有 $68.66 \%$ 的同学认为自己所接受的教学方式 是 “传统式教学, 少数老师以课本一讲到底”, 58. 96\%的同学 的体验是 “翻转式教学, 学生课程自学以后以 ppt或者演讲形 式呈现”。无论是传统教学还是翻转式教学, 教师教学核心在 于理论知识, 即使是档案管理学这些实践操作性较强的课程 也主要以理论课为主, 闭卷考试方式来评判学生所学的知识, 单一的理论教学使学生缺乏实践操作能力。

从 “影响学生学习积极性的原因分析” 来看, 有 $58.96 \%$ 的同学认为教师的授课方式对于他们学习有影响, 在对教学 改革建议时, 有同学提出: “专业老师在授课上可以多点花样, 不仅是老师一个人讲, 要把课堂氛围活跃起来; 考核方式不 仅是期末出几道大题死记硬背, 要考的更活一点。”

\section{3 实践课程现状与评价}

调查表明, 59. 87\%的同学反映实践课程设置偏少, 除毕 业实习外, 课程实践操作几乎都是电脑室上课。一方面学生 对于实践课程的渴望, 另一方面实践教学在培养环节中却是 薄落环节。理论与实践是教学中相辅相成的两个环节, 如何 更契合地把专业知识实践能力的培养运用到本专业职业能 力的培养中, 使二者相融合, 这是学院向应用型本科教育转 型进程中要攻克的首要难关。

\section{4 师资队伍现状及其需求}

独立学院教师以母体高校的师资为主, 自主招聘的教师 较少, 而母体档案学专业教师中, 以研究型、理论型教师为主, 但较少参与档案实际工作。档案学专业大多课程是具有实践 性的, 如果一概用理论教学方式, 会使学生感到枯燥乏味。从 调查看出, $88.15 \%$ 的同学认为, 独立学院自主招聘优秀教师 
非常必要, 学生接受知识的过程主要在于教师的传授, 这就 要求教师对档案实际工作具有广博知识和丰富经验, 在课堂 教学时与学生互动, 培养学生的综合素质。

\section{3 独立学院档案学专业教学改革的基本路径}

3. 1科学设置专业课程

档案学专业的人才培养应建立在应用型基础上, 课程设 置应增加实践性。笔者认为, 档案学专业可以采取理论与实 践相结合的课程形式, 科学设置理论与实践的学分学时。如 这些实践性强的课程: 《档案管理学》《社会调查研究方法》 《信息检索》《档案文献编纂学》《应用文写作》《文献保护 技术学》等。可以在增加实践课的基础上,一些偏重理论的 课程一周 3 学时, 讲授与实践学时可以调整为 $2+1$ 的形式设置, 偏重实践的课程, 讲授与实践学时可以调整为 $2+2$ 或 $1+3$ 的形 式设置。将理论课与实践课的学分学时进行科学合理分配。 与此同时, 加强特色课程的建设力度, 适当增加技术课程和 社会实践课程的比重和课时数。

\section{2不断改进教学方法}

在教学改革中通过引入多样化的教学方法, 激发学生学 习的兴趣, 培养学生独立思考的能力。案例教学、沙龙式教 学、启发式教学等受到大部分学生的赞同。案例教学法, 主 要通过教师对现实情况和实际问题的调查, 运用鲜活的案例 对某一课程内容进行实际讲解, 有助于学生对内容的深刻记 忆与理解。启发式教学是以学生为主体, 教师为主导的理念 教学, 老师可以利用某一工具或者一些视频来引导学生自己 去思考问题、解决问题。引入多样化教学方法有助于激发学 生主动参与学习的积极性, 使学生在学习知识、技能的过程 中, 不断提高学生创新精神、创造性思维、创造能力。

3. 3加强实践能力培养

加强学生实践能力的培养是独立学院档案学专业进行 教学改革的关键所在, 通过开设校内实验课程以及建立校外 “第二课堂” 势在必行。根据档案学专业课程设置情况, 在 校内可建立纸质档案和电子档案实习实训中心。纸质档案实 验室的应配备好废旧档案、档案盒、页码机、切割机、打孔 机、档案架等设备, 电子档案室配备电脑以及扫描仪等基础 设备, 在实践过程中让学生了解档案管理的整个流程, 保护 纸质档案等; 把理论知识发挥到实践中去, 真切感受真实的 档案工作。建立校外 “第二课堂”, 开启实践基地。校外实
训基地是对学生在就业前进行专业理论实践化、职业能力应 用塑造的首要场所, 学院可以与当地档案馆(局)、企事业单 位的档案部门联系, 开展短期实际工作实习, 使学生接触到 最新的档案工具以及了解档案工作的实际内容, 对档案工作 有一个感性的认识。也可以让工作单位和学生互相认识, 为 学生提供一个就业方向也为企事业单位寻找人才提供渠道。

3. 4建设 “双师型” 师资

采用 “双师型” 教学也是独立学院转型改革成功的重要 因素之一。一方面, 加大对青年教师的培养力度, 对青年教师 进行挂职锻炼, 到企事业单位实践基地参加档案实际工作, 在实践中掌握新技能新技术, 同时了解市场对档案人才的需 求导向, 获得档案工作发展的最前沿信息, 有助于提高教师 的教学水平。另一方面, 建立兼职教师队伍, 扩大兼职教师的 比例。学校可以聘请档案馆(局)或者企事业单位长期从事档 案工作的专家担任实践教学老师, 或者开设对档案行业前沿 技术水平相关方面的讲座, “双师型” 师资对应用型本科院 校人才培养模式转变具有重要意义。

\section{[参考文献]}

[1]周耀林,刘婧.论以实践为导向的档案学专业本科课 程体系改革一一武汉大学为例 [C].//第三届中美数字时代 图书馆情报学教育国际研讨会论文集,2010:1-9.

[2]李昂, 史江. 以市场需求为导向的档案学本科教育改 革发展路径初探[J].档案学通讯,2009(05):63-66.

[3]王巧玲,谢永宪,吴晓红,等.校外人才培养基地建设视 野下档案学专业实习实训项目的研发探索与实践——以北 京联合大学为例 [J]. 档案学通讯,2016(05):100-104.

[4]邱章强.基于应用型人才培养的独立学院实践教学发 展研究[J].江苏高教,2016(1):76-78.

[5]斯荣喜,龚山平,邹晓东.独立学院应用型创新人才培 养模式探索[J].高等工程教育研究,2005(1):73-75.

\section{作者简介：}

张明(1957--), 男, 江苏泰兴市人, 汉族, 学历大学, 教授, 研 究方向: 档案管理与社会服务。

吴琳月 $(1997--)$, 女, 江西抚州人, 汉族, 学历本科, 研究方 向: 档案学教学发展。

苏州大学文正学院 2017 高等教育改革研究课题。 